\title{
Studies on yersiniosis in cultured Mugil seheli for the first time in Suez Governorate
}

\author{
Eissa, I.A.M*; El-Ashram, A.M.M ${ }^{* *}$ and Yasmine, A. El-Barbary ${ }^{* *}$ \\ * Fish Diseases and Management Dept. Faculty of Vet. Med., Suez Canal University \\ ${ }^{* *}$ Fish Health and Diseases Dept. Faculty of Fish Resources, Suez University, Egypt.
}

\begin{abstract}
A total of 360 cultured Mugil seheli had clinical signs were collected from private farms in Suez Governorate, Egypt. $M$. seheli was subjected to clinical, post -mortem and bacteriological examinations for detection of Yersinia ruckeri. Yersinia ruckeri was identified by biochemical reactions and polymerase chain reaction (PCR). One isolate of Y. ruckeri. The results revealed that the presence of Yersinia ruckeri infection was $68.1 \%$. The highest prevalence of $Y$. ruckeri infection in cultured $M$. seheli was during autumn season (80\%) followed by spring (72.2\%), summer (70\%) and then winter (50\%). PCR amplification of DNA from $Y$. ruckeri isolates using 16s rRNA (YER8/10) specific primers for $Y$. ruckeri resulted in PCR products size of $575 \mathrm{bp}$. All $Y$. ruckeri isolates were found to be sensitive to Ciprofloxacin, Tobramycin and Trimethoprim. While resisted Erythromycin, Amoxycillin and Novobiocine.
\end{abstract}

\section{Introduction}

Fish constitute a major source of protein, fatty acids, vitamins, minerals and essential micronutrients for an expanding segment of the world population. Consequently, aquaculture is the fastest growing food production sector and accounts for approximately 50\% of the fish consumed worldwide (Mathiesen, 2015). Mugil seheli (M. seheli) is recognized as economically-important marine and brackish water fish and abundantly cultured in Suez Governorate, Egypt, for domestic consumption. $M$. seheli may be an excellent candidate for aquaculture especially in North Egypt regions because of its nutritional value.

Disease outbreaks have become a major constraint to the expansion of aquaculture and have a significant impact on the economic development of many countries. Bacterial pathogens are among the most important serious fish diseases in aquaculture causing $80 \%$ of fish mortalities (Woo and Bruno, 1999). Most of the bacteria, associated with these diseases, are saprophytic and widely distributed in the aquatic environment (ElAshram and Abd El-Rahman 2006; Austin and Austin 2007 and 
Plumb and Hanson 2011). Enteric redmouth disease (ERM, yersiniosis) is one of the most important diseases of salmonids and leads to significant economic losses (Horne and Barnes 1999). The disease is caused by Yersinia ruckeri, It's a Gram-negative rod-shaped enterobacterium, which was first isolated from rainbow trout (Oncorhynchus mykiss) in USA (Ross et al., 1966) and is currently found throughout North and South America, Europe, Australia, South Africa, the Middle East and China (Tobback et al., 2007 and Shaowu et al., 2013).

16s rRNA gene (YER8/10) primer was used to identify $Y$. ruckeri and gave a $575 \mathrm{bp}$ band when tested by means of PCR using these primers (Eissa et al., 2008).

The aim of the current investigation was to throw light on detection of $Y$. ruckeri in cultured $M$. seheli in Suez Governorate, Egypt with special reference to detection of 16s rRNA gene as diagnostic tool.

\section{MATERIALS AND METHODS}

Naturally infected $360 \mathrm{M}$. seheli were collected from private fish farms in Suez Governorate using gill nets method described by Portt (2006). The average body weight and length were $39.11 \mathrm{gm}$ and $15.17 \mathrm{~cm}$ respectively. Fish samples were subjected to clinical, post-mortem and bacteriological examinations (Noga, 2010, Meyers, 2006 and Austin and Austin, 2007). The prevalence of $Y$. ruckeri seasonally infected fish and organs also were recorded.

\section{Clinical and Postmortem Examinations:}

Clinical and post-mortem examinations were carried out according to Noga, (2010) and Meyers, (2006).

\section{Isolation and identification of $Y$. ruckeri}

Under complete aseptic condition, samples of gills and internal organs (liver, kidney and spleen) were collected from diseased M. seheli and cultivated on tryptic soy agar (Micromaster) ${ }^{\circledR}$ supplemented with $1 \%$ $\mathrm{NaCl}$ and incubated at $25^{\circ} \mathrm{C}$ for $24-48$ hours (Buller, 2014). Colonies from general media were streaked on Yersinia selective agar base (Micromaster) ${ }^{\circledR}$ supplemented with Yersinia selective supplement. The plates were incubated at $25^{\circ} \mathrm{C}$ for $24 \mathrm{hrs}$. Separated colonies were described and pure culture was identified using phenotypical and biochemical characters according to The biochemical tests were used for identification of bacterial isolates.

\section{DNA extraction and PCR assay}


Genomic DNA was extracted from bacterial isolates as described by Devi et al., (2009). The broth culture of bacterial isolates incubated at 37 ${ }^{\circ} \mathrm{C}$ for $16-18 \mathrm{hrs}$, Then centrifuged $(10,000 \mathrm{rpm}, 1 \mathrm{~min})$ to obtain a pellet, which was then washed with normal saline $(0.85 \mathrm{w} / \mathrm{v})$ and suspend pellet of cells in sterile distilled water $(0.5 \mathrm{ml})$. Suspended pellets were placed in boiling water bath at $98 \pm 2{ }^{\circ} \mathrm{C}$ for $15-20 \mathrm{~min}$ in a water bath to lyse the cells. The lysate was centrifuged to remove the cell debris $(10,000 \mathrm{rpm}, 5$ $\mathrm{min})$. The supernatant was obtained and stored $\left(-20^{\circ} \mathrm{C}\right)$ until further use. Primer specific for 16s rRNA of Yersinia ruckeri was used for PCR protocol under specific condition which was done twice. The first one was done exactly according to Gibello et al., (1999) and the second trial was achieved as previous but with some modification of the annealing temperature. The modification was 25 cycles of denaturation for $1 \mathrm{~min}$ at $92^{\circ} \mathrm{C}$,annealing was raised to $62{ }^{\circ}$ for $1 \mathrm{~min}$, and extension for $1 \mathrm{~min}$ at $72^{\circ} \mathrm{C}$, followed by a final extension step of $72^{\circ} \mathrm{C}$ for $5 \mathrm{~min}$. PCR amplified product was subjected to Gel electrophoresis in $1.5 \%(\mathrm{w} / \mathrm{v})$ agarose gel, using TAE (tris-acetate-EDTA) as running buffer and the power was supply adjusted at 100 volt for 20-30 minutes (lee et al., 2012).

\section{Challenge test}

A total of 20 apparently healthy acclimated $M$. seheli were divided into two equal groups in glass aquaria filled with pond water supplemented with continuous aeration using electrical pump for a week before injection. First group injected intraperitoneally with $0.1 \mathrm{ml}$ of $Y$. ruckeri 5 $\times 10^{5}$ CFU (Berc et al., 1999). The second group injected with sterile saline by using one $\mathrm{ml}$ insulin syringe. The experimentally infected fish were daily observed up to 14 days for any abnormal clinical signs and mortalities. Mortality rate was calculated for each group and re-isolation of injected bacteria was done.

\section{Sensitivity test to antibiotic}

A total of randomly selected five $Y$. ruckeri isolates recovered from naturally infected $M$. seheli were used in antimicrobial susceptibility test. Susceptibility was determined by the disc-diffusion technique on MuellerHinton agar plates (CLSI, 2013). Y. ruckeri pure cultures were grown in brain heart infusion (BHI) broth for 24 hours at $37^{\circ} \mathrm{C}$ (Samal et al., 2014). The suspension was swabbed on Mueller-Hinton medium plates. Discs were placed on inoculated plates and incubated for 24 hours at $37^{\circ} \mathrm{C}$ (Thakur et al., 2003 and Aravena-Román et al., 2012). The antibiotic discs were used Amoxicillin, Ciprofloxacin, Erythromycin, Naldixic Acid, Novobiocin, Tobramycin and Trimethoprim. Isolates were 
judged as sensitive (S), intermediately resistant (I) or resistant (R) on the basis of the size of the zone of bacteria growth inhibition according to the guidelines of the CLSI (2013).

\section{Results}

\section{Clinical findings}

The most common findings were hemorrhages on skin at different parts of the body, hemorrhages at the base of fins, on operculum and anal opening, swelling of abdomen (Plate 1, A). Some fish exhibited sluggishness, darkening of the fish coloration, swimming near the water surface with air gasping and bulging eyes. Affected fish showed loss of equilibrium and exhibited abnormal swimming behavior.

\section{Post- mortem findings}

The post-mortem finding of naturally infected $M$. seheli showed petechial hemorrhages of the most internal organs and erythematous intestinal mucosa (Plate 1, B). In other cases, the intestines voided of feed and contained yellowish mucus. Congested and enlarged spleen also was observed (Plate 1, C). Moreover, enlarged and congested kidney and liver were also noticed.

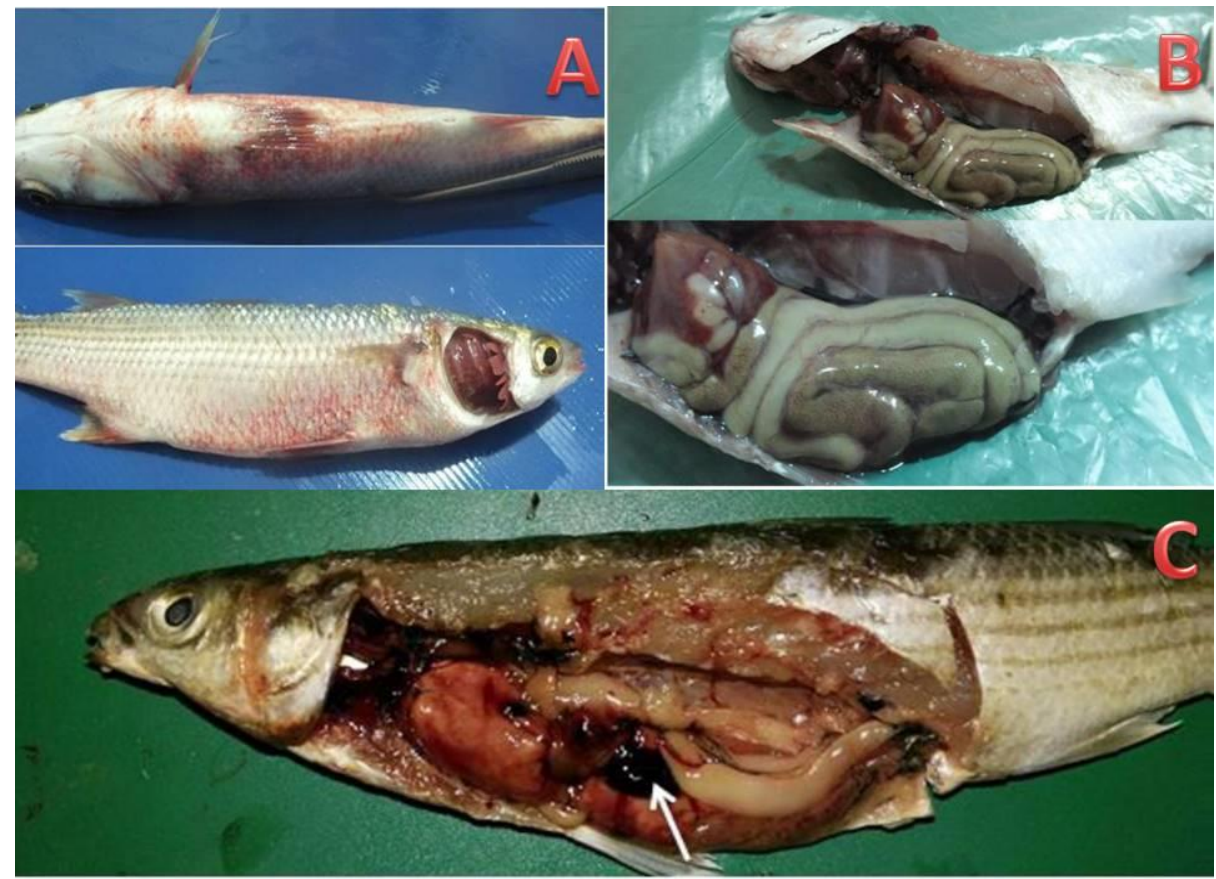

Plate (1): Naturally infected $M$. seheli showing hemorrhages on external body surface (A), petechial hemorrhages on intestinal external surface (B) and enlarged and congested spleen (arrow) and pale liver with hemorrhages $(\mathbf{C})$. 


\section{Bacteriological examination}

The phenotypic and biochemical characters of isolated bacteria from naturally infected $M$. seheli were illustrated in (Table 1).

Morphological and biochemical identification (Table 1)

Table (1) Morphological and biochemical identification of Y. ruckeri

\begin{tabular}{lc}
\hline Test & Result \\
\hline Gram staining & - \\
Colonies character on Yersinia & Pink colonies with red center \\
selective agar base & + \\
Motility & - \\
Oxidase & + \\
Catalase & + \\
Ornithine decarboxylase & - \\
Indol & - \\
H2S & + \\
Glucose fermentation & + \\
Citrate utilization & - \\
Gelatin liquification & + \\
Methyle red & + \\
\hline
\end{tabular}

Prevalence of $Y$. ruckeri isolates in naturally infected Mugil seheli:

Total prevalence of $Y$. ruckeri infection in naturally infected $M$. seheli:

The total prevalence of Yersinia ruckeri infection was $68.1 \%$ among the examined fish.

Seasonal prevalence of $Y$. ruckeri infection in naturally infected $M$. seheli:

The prevalences of $Y$. ruckeri infection in cultured Mugil seheli were $80 \%$ in autumn followed by $72.2 \%$ in spring, $70 \%$ in summer and $50 \%$ in winter. 


\section{Prevalence of $Y$. ruckeri infection in organs of naturally infected $M$. seheli:}

The majority of Yersinia ruckeri isolates were recovered from gills $41.7 \%$ followed by liver $29.55 \%$ and kidney $25.1 \%$. While the lowest percentage was recovered from spleen $3.64 \%$.

\section{Experimental infection of $M$. seheli with $Y$. ruckeri}

The mortality rate of experimentally infected $\mathrm{M}$. seheli with $Y$. ruckeri isolate was showed in (Table 2). The most cases of experimentally infected fish suffered from abnormal swimming, darkening of the skin and loss of equilibrium within $24 \mathrm{hrs}$ post-injection. Also, severe diffused external hemorrhages on the body of experimental infected fish, redness of all fins in some cases; severe congestion and redness of the mouth were observed (Photo 1).

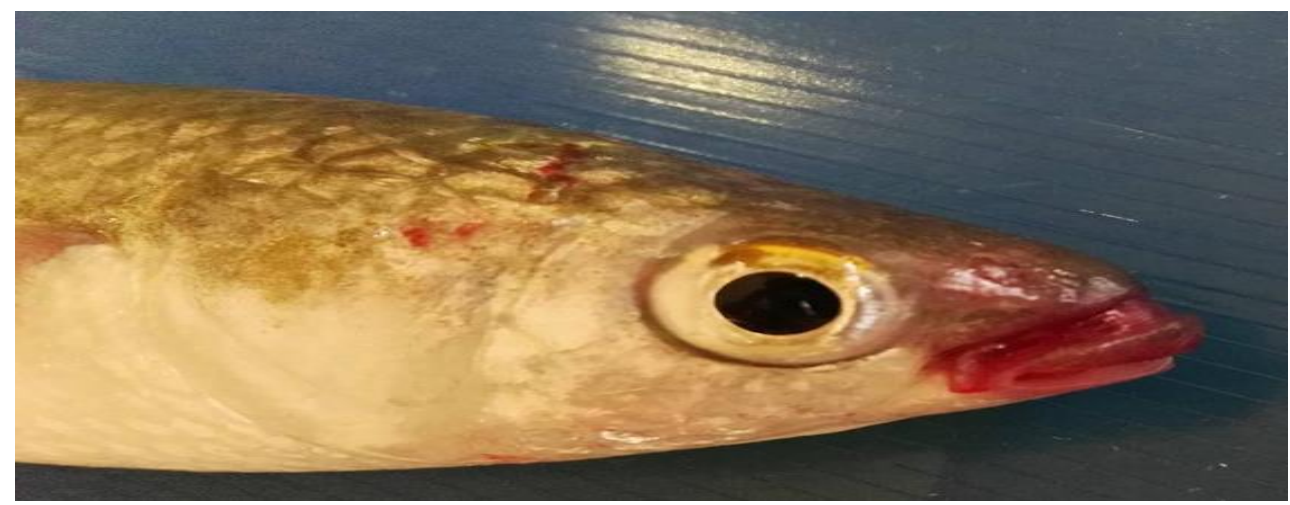

Photo (1) Mugil seheli artificially infected with Yersinia ruckeri showed sever hemorrhage of the mouth area.

Table (2): Results of pathogenicity of $Y$. ruckeri used in challenge test

\begin{tabular}{cccccccc}
\hline $\begin{array}{c}\text { Injected } \\
\text { bacteria }\end{array}$ & $\begin{array}{c}\text { No. of } \\
\text { infected } \\
\text { fish/control }\end{array}$ & $\begin{array}{c}\text { Average } \\
\text { weight } \\
\text { of fish }\end{array}$ & $\begin{array}{c}\text { Dose } \\
\text { (CFU/Fish) }\end{array}$ & $\begin{array}{c}\text { Method of } \\
\text { infection }\end{array}$ & $\begin{array}{c}\text { No. } \\
\text { of } \\
\text { dead } \\
\text { fish }\end{array}$ & $\begin{array}{c}\text { Mortality } \\
(\%)\end{array}$ & $\begin{array}{c}\text { Post- } \\
\text { infection } \\
\text { days of } \\
\text { mortality }\end{array}$ \\
\hline $\begin{array}{c}Y . \\
\text { ruckeri }\end{array}$ & 10 & $30.5 \mathrm{~g}$ & $5 \times 10^{5}$ & Intraperitoneal & 6 & 60 & $3-7$ \\
Control & 10 & & $\begin{array}{c}0.1 \mathrm{ml} \\
\text { saline }\end{array}$ & & 0 & 0 & - \\
\hline
\end{tabular}




\section{Molecular identification by PCR}

Tested seven bacterial isolates gave the expected bands of 575 bp size in lane one to seven when the $Y$. ruckeri specific 16s rRNA primers were used for molecular identification (Photo 2) by modified protocol (Table $3,4)$.

Table (3) Specific primers of $Y$. ruckeri, Annealing temperature and number of cycles used in DNA amplification of each isolate:

\begin{tabular}{llllll}
\hline Bacteria & $\begin{array}{l}\text { Name of } \\
\text { primers }\end{array}$ & $\begin{array}{l}\text { Gene } \\
\text { product }\end{array}$ & Forward/ Reverse & AT & C \\
\hline $\begin{array}{l}\text { Yersinia } \\
\text { ruckeri }\end{array}$ & YER 8, & 16s rRNA 10 & & $\begin{array}{l}\text { F:GCGAGGAGGAAGGGTTAAGTG } \\
\text { R: GAAGGCACCAAGGCATCTCTG }\end{array}$ & 25 \\
& & & Gibello et al., 1999 and Altinok 2001 & & \\
\hline
\end{tabular}

$\mathrm{AT}=$ Annealing temperature $\mathrm{C}=$ Number of cycles

Table (4) Standard MyTaq ${ }^{\text {TM }}$ Mix Protocol

\begin{tabular}{ll}
\hline Template & $200 \mathrm{ng}$ \\
Forward primers $(20 \mathrm{pmol})$ & $1 \mu \mathrm{l}$ \\
Reverse primers $(20 \mathrm{pmol})$ & $1 \mu \mathrm{l}$ \\
MyTaq Mix, 2x & $25 \mu \mathrm{l}$ \\
\hline Water & Up to 50 $\mu \mathrm{l}$ \\
\hline
\end{tabular}

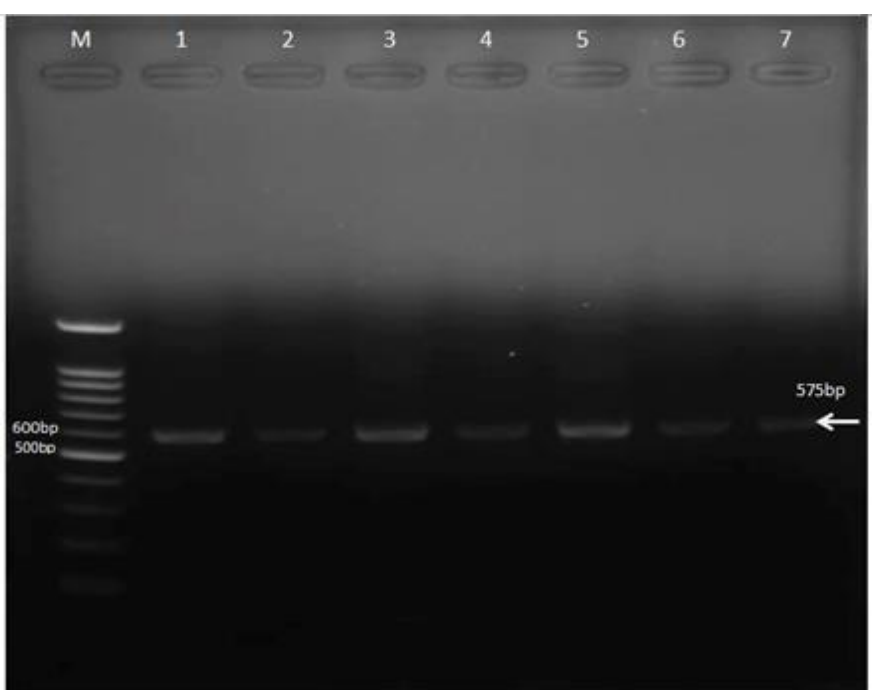

Photo (2) PCR amplification of DNA from Yersinia ruckeri isolates using specific primers for $Y$. ruckeri resulted in PCR products size of $575 \mathrm{bp}$. 


\section{Antibiogram sensitivity of $Y$. ruckeri}

All Yersinia ruckeri isolates were sensitive to Ciprofloxacin, Tobramycin and Trimethoprim. While resisted Erythromycin, Amoxycillin and Novobiocine (Table 5).

Table (5) Antibiogram profile of $Y$. ruckeri

\begin{tabular}{|c|c|c|c|c|c|}
\hline \multirow[t]{2}{*}{ Antibiotic } & \multicolumn{3}{|c|}{ Break point (mm) } & \multirow{2}{*}{$\begin{array}{c}\text { Average } \\
\text { inhibitory zone } \\
\text { of isolates }(\mathrm{mm})\end{array}$} & \multirow[t]{2}{*}{ Sensitivity of isolates } \\
\hline & $\mathrm{S}$ & I & $\mathrm{R}$ & & \\
\hline Aml $(10 \mu \mathrm{g})$ & $>18$ & $14-17$ & $<13$ & 10 & $\mathrm{R}$ \\
\hline Cipro $(5 \mu \mathrm{g})$ & $>31$ & $21-30$ & $<20$ & 45 & $\mathrm{~S}$ \\
\hline$E(15 \mu g)$ & $>23$ & $14-22$ & $<13$ & 10 & $\mathrm{R}$ \\
\hline NA $(30 \mu g)$ & $>19$ & $14-18$ & $<13$ & 10 & $\mathrm{R}$ \\
\hline NV $(30 \mu g)$ & $>22$ & $18-21$ & $<17$ & 10 & $\mathrm{R}$ \\
\hline TMP $(5 \mu \mathrm{g})$ & $>16$ & $11-15$ & $<10$ & 35 & $\mathrm{~S}$ \\
\hline ТОВ $(10 \mu \mathrm{g})$ & $>15$ & $13-14$ & $<12$ & 16 & $S$ \\
\hline
\end{tabular}

Aml = Amoxycillin, cipro =ciprofloxacin, $\mathrm{E}=$ erythromycin, $\mathrm{NA}=$ naldixic acid, $\mathrm{NV}=$ novobiocin, $\mathrm{TMP}=$ trimethoprim, $\mathrm{TOB}=$ tobramycin, $\mathrm{S}=$ sensitive, $\mathrm{I}=$ intermediate resistant, $\mathrm{R}=$ resist.

\section{Discussion}

The most common clinical signs of naturally infected fish were swimming near the surface of water, congested or pale gills, hemorrhages at the base of fins, abdominal part and gill cover, hemorrhages around the vent and mouth and some fish displayed abdominal distension. Similar picture was noticed by Oren (1981), El-Ashram and Abd El-Rahman (2006) and Enany et al., (2011).

The results of postmortem examination of naturally infected fish revealed pale liver in some cases and in other cases liver were hemorrhagic. Kidneys and spleen were enlarged and congested. These results went hand in hand with that observed by El-Ashram and Abd El-Rahman (2006) and Enany et al., (2011).

Regarding to the bacteriological examination, Yersinia ruckeri was Gram negative short rod bacilli, grew on Yersinia selective agar base that not agreed with Buller, (2014) who reported that Yersinia ruckeri didn't grow on Yersinia selective agar base. Yersinia ruckeri in present study was oxidase negative and catalase positive. It was negative for hydrogen 
sulphide production, indol production and gelatin liquefaction tests while positive for citrate utilization, ornithine decarboxylase and methyle red test. This finding was supported by Altun et al., (2013).

The mortality rate of Yersinia ruckeri in experimentally infected $M$. seheli fish was $60 \%$ in the present study. This result was nearly in line with that obtained by Ohtani et al., (2016) who reported that the mortality of $Y$. ruckeri IP experimentally rainbow trout (Oncorhynchus mykiss) was $64 \%$.

Yersinia ruckeri PCR assay using YER 8, YER 10 primers according to Gibello et al., (1999) showed that the use of annealing temperature $60^{\circ}$ $\mathrm{C}$ as indicated by them led to the appearance of non-specific bands. Therefore the temperature of annealing step was raised to $62^{\circ} \mathrm{C}$ in the present study (higher than that used by Gibello et al., 1999) to avoid the appearance of non-specific bands, bacterial isolates gave the expected bands of $575 \mathrm{bp}$.

Yersinia ruckeri was isolated from cultured Mugil seheli which reared in brakish water in Suez governorate, Toranz, (2004) cited that Yersinia ruckeri was documented in cultured fresh and seawater fish. The total prevalence of Yersinia ruckeri in cultured Mugil seheli was $68.1 \%$. These results were nearly in line with that obtained by Eissa et al., (2008) who reported the prevalence of $Y$. ruckeri infection in cultured Nile tilapia, Oreochromis niloticus in Egypt was 66.6\%.While Aly (2013) mentioned that incidence of $Y$. ruckeri in grey mullet was $20 \%$.

All $Y$. ruckeri isolates were found to be sensitive to Ciprofloxacin, Tobramycin and Trimethoprim. While resisted Erythromycin, Amoxycillin and Novobiocine, these resulted supported by Akhlaghi and Sharifi Yazdi (2008) and Lazar et al., (2010).

It could be concluded that yersiniosis is one of the most important bacterial disease of cultured $M$. seheli and leads to significant economic losses. Ciprofloxacin, Tobramycin and Trimethoprim are the drugs of choice to control the disease. PCR is most sensitive and rapid method for identification Yersinia ruckeri pathogen.

\section{REFERENCES}

Akhlaghi, M. and Sharifi Yazdi, H., (2008): Detection and identification of virulent Yersinia ruckeri: the causative agent of enteric redmouth disease in rainbow trout (Oncorhynchus mykiss) cultured in Fars province, Iran. Iranian Journal of Veterinary Research, 9(4), pp.347-352. 
Aravena-Román, M., Inglis, T. J., Henderson, B., Riley, T. V., and Chang, B. J. (2012): Antimicrobial susceptibilities of Aeromonas strains isolated from clinical and environmental sources to 26 antimicrobial agents.Antimicrobial agents and chemotherapy, 56(2), 1110-1112.

Altun, S., Onuk, E. E., Ciftci, A., Duman, M., \& Büyükekiz, A. G. (2013): Determination of Phenotypic, Serotypic and Genetic Diversity and Antibiotyping of Yersinia ruckeri Isolated from Rainbow Trout. Kafkas Üniversitesi Veteriner Fakültesi Dergisi, 19(2), 225-232.

Aly, S. M. (2013): A review of fish diseases in the Egyptian aquaculture sector: Working report. CGIAR Research Program on Livestock and Fish, 1-25

Aravena-Román, M., Inglis, T. J., Henderson, B., Riley, T. V., and Chang, B. J. (2012): Antimicrobial susceptibilities of Aeromonas strains isolated from clinical and environmental sources to 26 antimicrobial agents.Antimicrobial agents and chemotherapy, 56(2), 1110-1112.

Austin, B., and Austin, D. A. (2007): Bacterial fish pathogens: Disease of farmed and wild fish. Fourth edition. Springer Science \& Business Media.

Berc, A., Petrinec, Z., Matašin, Ž. \& Kozarić, Z. (1999): Yersinia ruckeri septicaemia in experimentally infected carp (Cyprinus carpio L.) fingerlings. Acta Veterinaria Hungarica, 47(2), 161-172.

Buller, N. B. (2014): Bacteria and Fungi from Fish and other Aquatic Animals: a practical identification manual. CABI. page $15,16,114,128,169,235,446$ and 706 .

Clinical and Laboratory Standards Institute (CLSI) (2013): Informational Supplement; CLSI document M100-S21,Wayne, PA, USA. Vol. 31 No. 1 Pages13, 43 to 46.

Devi, R., Surendran, P. K., and Chakraborty, K. (2009): Antibiotic resistance and plasmid profiling of Vibrio parahaemolyticus isolated from shrimp farms along the southwest coast of India. World Journal of Microbiology and Biotechnology, 25(11), 2005-2012.

Eissa, A. E., Moustafa, M., Abdelaziz, M., and Ezzeldeen, N. A. (2008): Yersinia ruckeri infection in cultured Nile tilapia, Oreochromis niloticus, at a semi-intensive fish farm in Lower Egypt. African Journal of Aquatic Science, 33(3), 283-286 
El-Ashram, A. M. M., and Abd El-Rahman, A. M. M. (2006): Studies on bacterial diseases infecting mullet (Mugil capito) cultured in freshwater farms in Sharkia province. J. Agric. Res., 84 (1B) 461-471.

Enany, M . EL., Ibrahim, H. M., Abou El Atta, M. El. and El Adawy, M. (2011): Bacteriological and histopathological studies on some bacterial pathogens causing diseases in cultured Mugil capito fish in Ismailia governorate. Suez Canal Veterinary Medicine Journal, XVI. $1-12$

Gibello, A., Blanco, M. M., Moreno, M. A., Cutuli, M. T., Domenech, A., Dominguez, L., and Fernández-Garayzábal, J. F. (1999): Development of a PCR Assay for Detection of Yersinia ruckeri in Tissues of Inoculated and Naturally Infected Trout. Applied and Environmental Microbiology, 65(1), 346-350.

Horne, M.T; Barnes, A.C (1999): Enteric redmouth disease (Yersinia ruckeri). Woo PTK, Bruno, Fish diseases and disorders. Viral, bacterial and fungal infections. CABI Publishing, Wallingford, pp 445-477

Lazar, M., Vulpe, V., Guguianu, E., Lazar, R., Sarli, G., and Oprean, O. Z. (2010): Red Mouth Disease in Rainbow Trout (Oncorhynchus mykiss)-a Case Report on Lake Trout Farm from Bicaz, Romania. Bulletin of the University of Agricultural Sciences \& Veterinary Medicine Cluj-Napoca. Veterinary Medicine, 67(1).

Lee, P. Y., Costumbrado, J., Hsu, C. Y., and Kim, Y. H. (2012): Agarose gel electrophoresis for the separation of DNA fragments. JoVE (Journal of Visualized Experiments), (62), 3923. Advance online publication. http://doi.org/10.3791/3923.

Mathiesen, Á. M. (2015): The state of world fisheries and aquaculture 2012. Food and Agriculture Organization of The United Nations. 97892-5-107225-7

Meyers, T. R. (2004): Standard necropsy procedures for finfish, second edition. National Wild Fish Health Survey-Laboratory Procedures Manual

Noga, E. J. (2010): Fish disease Diagnosis and Treatment. Mosbyyearbook, Inc. watsworth publishing Co., USA. pp.366.

Ohtani, M., Strom, H. K., Lauritsen, A.H., Villumsen, K.R., Dalsgaard, I., Raida, M.K and Bojesen, A.M. (2016): Influence of the challenge route on the pathogenicity of Yersinia ruckeri in rainbow trout (Oncorhynchus mykiss). International Conference Organized by the European Aquaculture Society in cooperation with Marine 
Scotland and The Marine Alliance for Science and Technology for Scotland, September 20-23, 2016, Edinburgh, Scotland.

Oren, O. H. (1981): Aquaculture of grey mullets. (Vol. 26). Cambridge University Press, U.K. pp. 1-19.

Plumb, J. A., and Hanson, L. A. (2011): Health maintenance and principal microbial diseases of cultured fishes. John Wiley \& Sons.

Portt, C. B., Coker, G. A., Ming, D. L., and Randall, R. G. (2006): A review of fish sampling methods commonly used in Canadian freshwater habitats. Can. Tech. Rep. Fish. Aquat. Sci. 2604 p

Ross, A.J; Rucker, R.R and Ewing, W.H (1966): Description of a bacterium associated with redmouth disease of rainbow trout (Salmo gairdneri). Can J Microbiol 12:763-770

Samal, S. K., Das, B. K., and Pal, B. B. (2014): Isolation, biochemical characterization, antibiotic susceptibility study of Aeromonas hydrophila isolated from freshwater fish. Int. J. Curr. Microbiol. App. Sci, 3(12), 259-267.

Shaowu, L; Di, W; Hongbai, L and Tongyan, L (2013): Isolation of Yersinia ruckeristrain H01 from farm-raised amur sturgeon Acipenser schrencki in China. J Aquat Anim Health 25:9-14

Thakur, A. B., Vaidya, R. B., and Suryawanshi, S. A. (2003): Pathogenicity and antibiotic susceptibility of Vibrio species isolated from moribund shrimps. Indian journal of marine sciences, 32(1), 7175

Tobback, E; Decostere, A; Hermans, K; Haesebrouck, F and Chiers, K (2007): Yersinia ruckeri infections in salmonid fish. J Fish Dis 30:257-268

Toranzo, A. E. (2004): Report about fish bacterial diseases. Mediterranean Aquaculture Laboratories, ed. Alvarez-Pellitero P, Barja JL, Basurco B, Berthe F, Toranzo AE, 49-89.

Woo, P. T. K. and Bruno, D. W. (1999): Fish diseases and disorders.Vol. 3,Viral, Bacterial and Fungal infections. CABI Publishing, London, U.K. 


\section{دراسات عن مرض الفم الأحمر المعوى لأول مرة فى أسماك السهلية المستزرعة

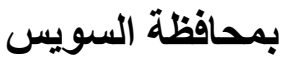

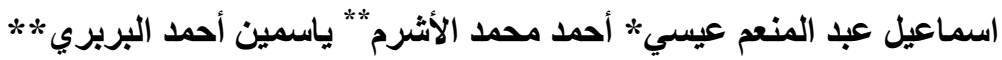

* قسم أمراض الأسماك ورعايتها - كلية الطب لبيطري - جامعة قناة السويس.

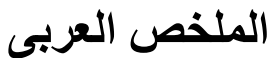

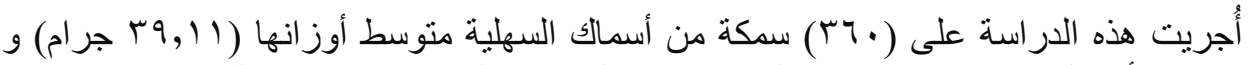

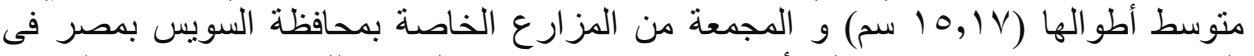

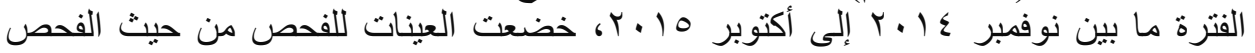

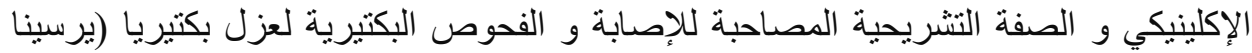

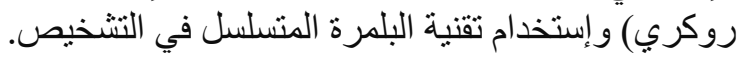

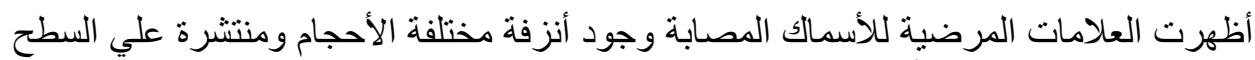

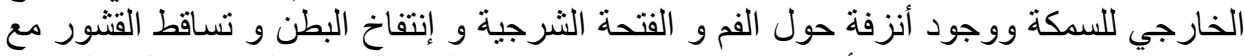

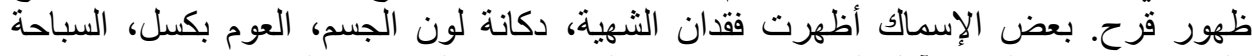

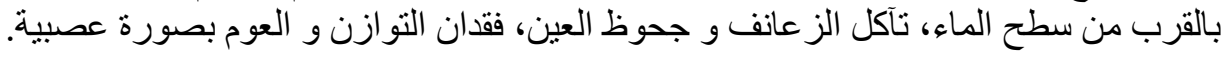

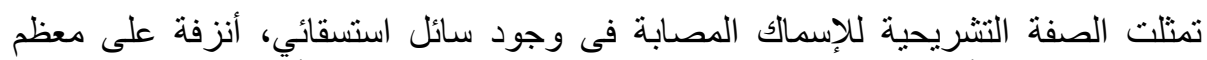

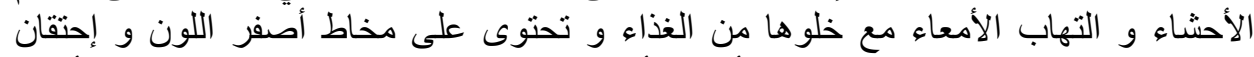

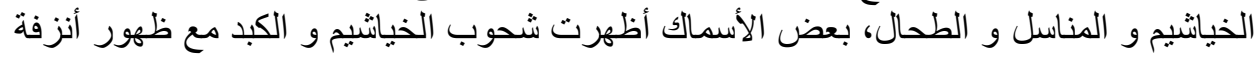
وضخامة و إحتقان في الكلي و الكبد.

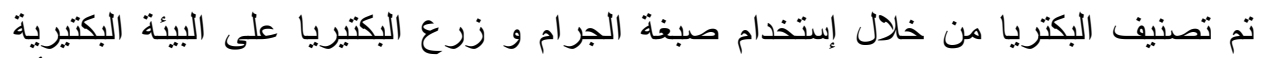

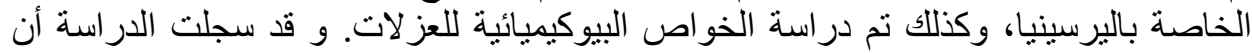

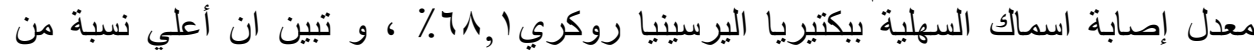

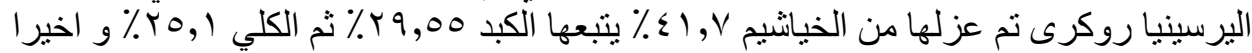

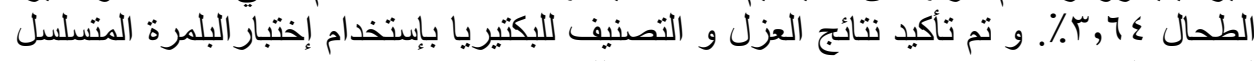

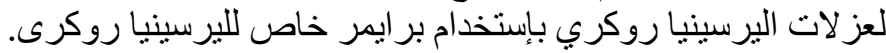

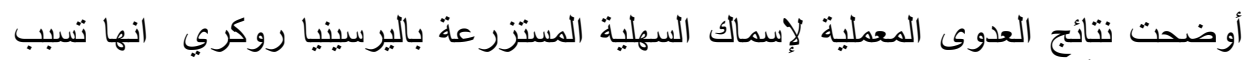

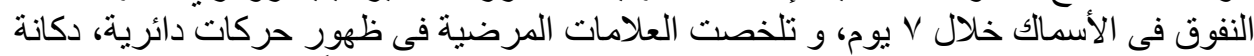

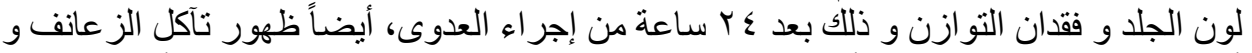

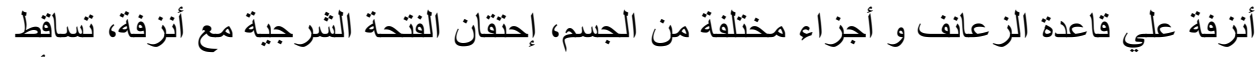

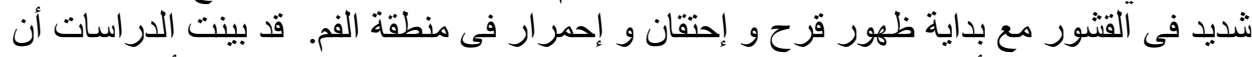

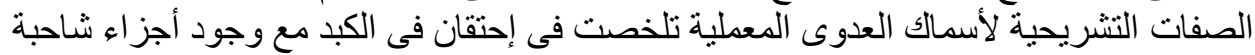

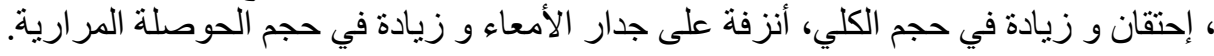

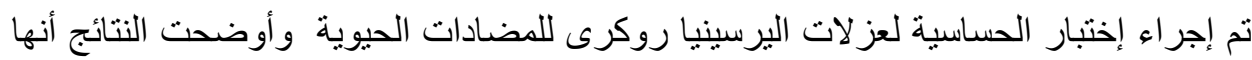

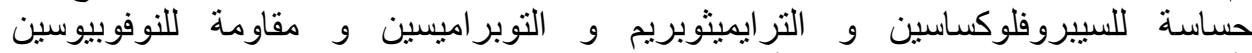
، أيرثروميسين، حامض النالدكسيك و أموكسيسلين. 